\title{
O FUNDO INCERTO DA CERTEZA: AS ESCULTURAS DE FRED SANDBACK
}

O ESPAÇO NAS ENTRELINHAS

Exposição de Fred Sandback. Rio de Janeiro: Instituto Moreira Salles; São Paulo: Instituto Moreira Salles/ Centro Universitário Maria Antônia, agosto-outubro 2010.

ALBERTO TASSINARI

Talvez nenhum escultor tenha feito um uso da profundidade do espaço em que suas obras se instalam de um modo tão decidido e decisivo quanto Fred Sandback. Suas esculturas são quase sempre feitas apenas com segmentos de retas, mas segmentos de tal forma arranjados que capturam para si as profundidades do espaço que compartilham com o espectador. É assim que três segmentos de reta formando um triângulo também desenham a área desse triângulo e não apenas suas arestas, mas, além disso, dado que a área se encontra desenhada no mesmo espaço em que se encontra o espectador, surgem um lá e um cá em torno dessa área ou, ainda, uma profundidade dividida em duas partes. E se um dos vértices do triângulo se apoia na parede e os outros dois no chão, a inclinação do triângulo chama o chão e a parede da sala de exposição para fazerem parte da obra, desenhando agora um poliedro piramidal.

São operações muito simples: delimitar as arestas de um triângulo e apoiá-lo no chão e na parede. Mas é justamente essa simplicidade que faz das esculturas de Sandback algo ao mesmo tempo sereno e enigmático. $\mathrm{O}$ enigma poderia ter, entre outras, a seguinte fórmula: como podemos ver mais do que vemos? E a serenidade, que sossega a possível instabilidade da visão como que responde: não se vê aqui nem mais nem menos do que se vê.

Não tenho a intenção de inventar paradoxos em torno de uma obra tão límpida e segura. Entretanto, diante do triângulo apoiado por um vértice na parede e por sua aresta oposta no chão, se vemos um poliedro, esse não é inteiramente definido. A área interior ao triângulo é totalmente definida, assim como o ângulo reto formado pela parede e o chão e que a obra suga para si. Mas o que dizer das outras faces? Não 
há linhas que indiquem áreas que delimitariam um volume inteiriço. Vemos então mais do que vemos porque não sabemos a localização exata de um poliedro que pressentimos existir, que está mais ou menos onde estamos, mas onde, ao certo, não sabemos. E se não vemos mais nem menos do que vemos é porque o ver, nas esculturas de Fred Sandback, é um contraponto entre determinação e indeterminação, entre áreas e localizações precisas e outras apenas possíveis. É desse ver que as obras de Sandback tratam, mais do que das linhas que as tracejam no espaço. Mesmo nas obras em que um sólido estaria inteiramente determinado, surge uma profundidade sem medida certa, pois o olhar ou se fixa na face mais próxima ou a vaza em direção às linhas de encontro da parede e do chão.

Aarte, entretanto, escreve-se por dimensões sensíveis. Essas arestas tão nítidas das esculturas não são lá tão nítidas assim. Feitas de lã acrílica e muitas vezes com dois ou três fios engrossando-as para melhor serem vistas, deixam os fios que se soltam da lã formar uma espécie de camada desfocada em torno delas. Como na pintura de Vermeer, em que a nitidez não vem dos contornos das coisas, mas do efeito como que evaporador que a luz, essa sim nítida ao extremo, produz nas coisas ao tocá-las, os fios de lã das esculturas de Sandback são tão mais nítidos quanto mais o olhar se esforça para fixá-los. Uma vez fixados, fixam tudo mais que podem: prumos, distâncias, áreas, verso e reverso. E mais não fixam porque o artista não fornece as arestas ou os planos opacos para uma completa determinação dos volumes. Do jogo de indeterminação e determinação dos contornos dos fios de lã - e sem os quais as esculturas perderiam plasticidade passa-se ao jogo maior de um ver que alterna a determinação e a indeterminação dos volumes.

A esse ver que contrapõe determinação e indeterminação - essa é a hipótese dessa breve nota - pode-se objetar que não nos é dado ver desse ou daquele modo, e que o ver, diferente do pensar e do dizer, é um só. $O$ argumento seria correto se um artista que tematiza o ver não o abordasse sempre por um viés, assim como o faz com a cor e outros tantos conteúdos. Mas que se pense a passos largos na grande aventura da perspectiva italiana de Giotto ao vedutismo de Canaletto para se fixar o quanto o ver, em cada grande pintor, é um ver diverso.

A alusão aqui a pintores, e pintores que ainda empregavam a técnica da perspectiva, talvez possa dar origem a confusões. As esculturas de Sandback, ao solicitarem as profundidades do próprio espaço em que as obras se instalam, guardam, é certo, um parentesco com a pintura perspectiva, na medida em que profundidade e perspectiva são termos próximos. Suas esculturas são "como que" desenhos perspectivos devolvidos do plano do papel ao espaço do mundo, mas que no papel só o dão a perceber por meio da ilusão. Porém, nessa nuança é 
que reside toda a diferença. As esculturas correlatas da época da pintura perspectiva dão a ver seres maciços e contornados, sem ambiguidades espaciais maiores. Não são esculturas que empregam o espaço que as ronda como parte intrínseca delas. Quando a perspectiva e, mais ainda, a profundidade óptica de uma pintura perdem eficácia a partir de meados dos anos de 1950, quando ela se torna um anteparo opaco que se volta para o mesmo espaço do espectador, com mais força ainda as esculturas deixam de ser formas que se isolam do espaço que as ronda e passam a incorporá-lo como parte das obras.

O exemplo definitivo dessa comunicação entre o espaço da obra e o espaço do mundo comum à obra e ao espectador são as esculturas em série de Donald Judd, que não por acaso foi professor de Sandback em Yale. A alternância entre os volumes postos em série e os vazios entre eles é também uma alternância entre espaços da obra e o espaço do mundo. E uma alternância constitutiva da obra, sem a qual ela não existe e não se individua.

Em Fred Sandback, porém, não é a alternância de cheios e vazios que é tematizada, mas, como já adiantado, entre planos e profundidades - profundidades do próprio mundo, do mesmo mundo e espaço em que se encontra o espectador. Sua semelhança meio que pelo avesso com uma pintura perspectiva vem do fato de que a perspectiva buscou uma linguagem que imitasse a visão. Visão e ver que as obras de Sandback, porém, não imitam, mas, ao contrário, põem a trabalhar como complementos da obra, como um ver que ao contrapor planos e profundidades não deixa de ser o ver de todos os dias, sem nenhuma intermediação ilusionista para o olhar. Se esse ver é levado, pelos segmentos de reta, a ser mais determinado do que o habitual é porque entra em cena aqui justamente as operações artísticas e estéticas que formam a obra que, para não se completar como um volume inequívoco, torna esse ver também mais indeterminado que de hábito. Em meio a arestas e planos tão certos ronda o incerto. Em meio à calma, inquietudes. Aproximamo-nos com cautela das obras. Não porque se imponham a nós e exijam distância. Esses claros enigmas, para emprestar a expressão de Drummond, logo que nos acenam já se mostram algo ardilosos. Capturam o espaço e suas profundidades como se fossem armadilhas de um caçador dispostas pela sala de exposição. Como em atos e experiências plenas de quietude em que vez ou outra a vida nos dá, aqui também sabemos que nenhuma serenidade se constrói sem alguma sorte a nos guiar sobre o terreno movediço das coisas. Com a diferença que o dom da arte, e de Fred Sandback, é nos proporcionar essa experiência em maior segurança, mais protegidos e mais gratos de apenas existir.

Alberto TASSINARI é crítico de arte e autor de O espaço moderno (Cosac Naify, 2001). 